\title{
FSH SUPPLEMENTATION INCREASES THE GROWTH OF PC-3 HUMAN PROSTATE CANCER CELL XENOGRAFT IN GONADOTROPIN-SUPPRESSED NUDE MICE
}

Olayiwola O Oduwole ${ }^{1}$, Ariel Poliandri ${ }^{2}$, Phil Rawson ${ }^{1}$, Nafis Rahman ${ }^{3}$, Wolfgang Koechling ${ }^{4}$ and Ilpo Huhtaniemi ${ }^{1,3}$

${ }^{1}$ Imperial College London, UK. ${ }^{2}$ Queen Mary University of London, UK. ${ }^{3}$ University of Turku, Finland. ${ }^{4}$ Ferring Pharmaceuticals Denmark

\section{INTRODUCTION:}

Gonadotropin-releasing hormone $(\mathrm{GnRH})$ analogues are now the standard hormonal treatment for prostate cancer ${ }^{1}$. A fundamental difference between $\mathrm{GnRH}$ agonist and antagonist treatment is the permanent suppression of both LH and FSH by antagonist (e.g. Degarelix), while a rebound in FSH is associated with agonist (e.g. Leuprolide) treatment (Figs. $1 \mathrm{~A}$ and B) ${ }^{2,3}$. The benefits of antagonist include the immediate onset of action and profound long-term suppression of FSH, suggested to be an independent growth factor in prostate cancer.

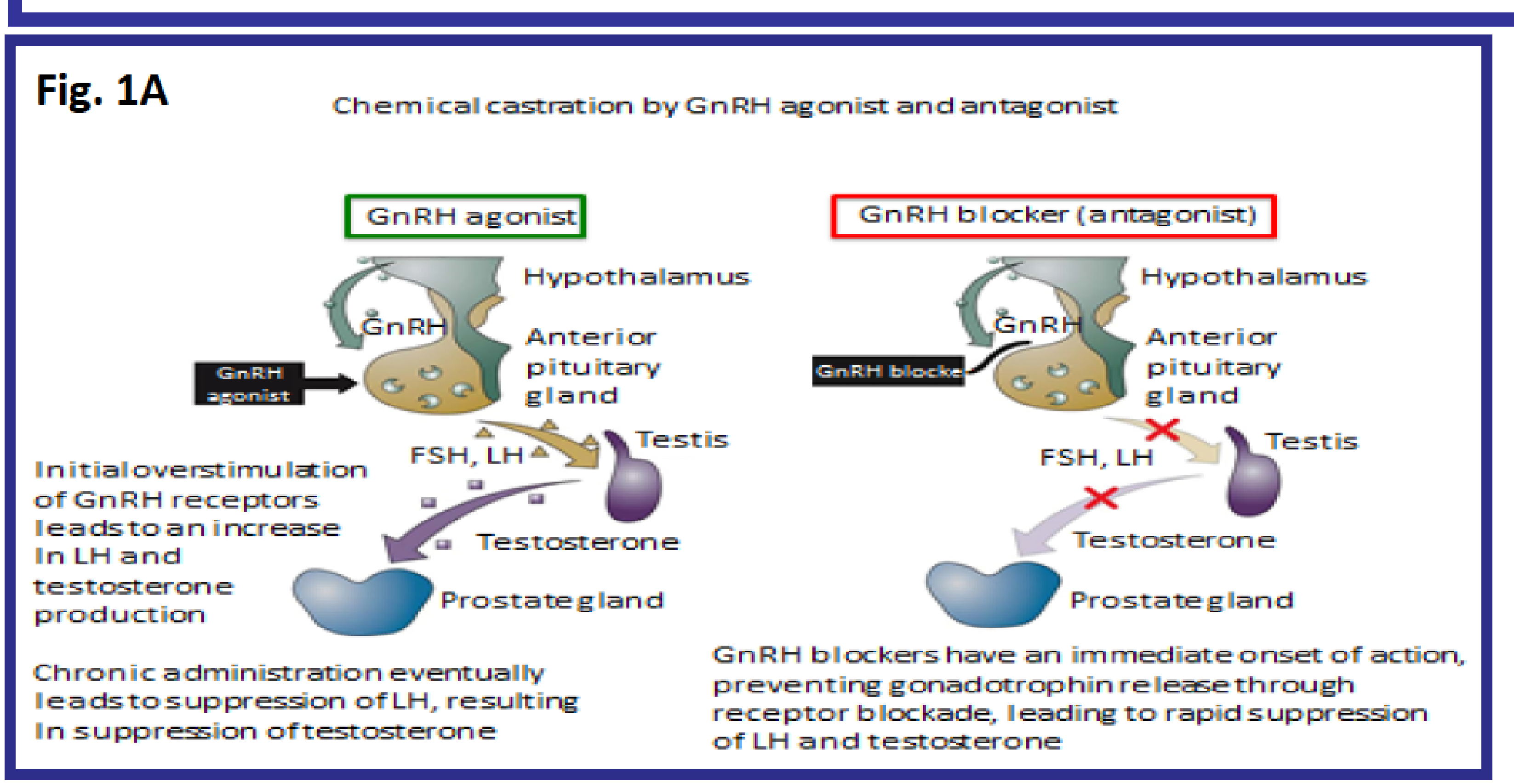

\section{AIMS:}

To assess the potential beneficial effects of permanent FSH suppression in the hormone ablation treatment of prostate cancer, we studied the effect of GnRH antagonist, degarelix, in the absence and presence of FSH supplementation on the growth of prostate cancer cell xenografts in athymic nude male intact and gonadectomised mice.
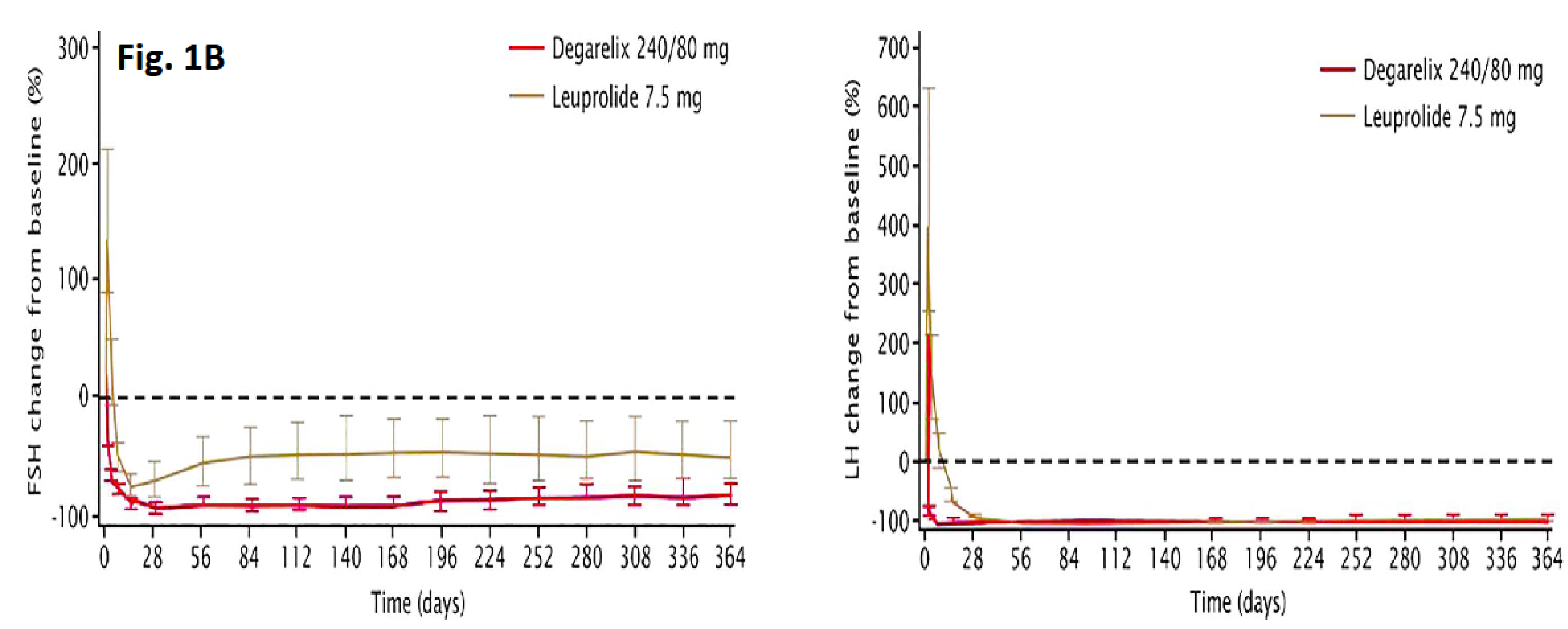

\section{METHODS:}

Nude male Intact mice (IM; $N=20)$ and gonadectomised mice (GM; N=20) were inoculated with $2 \times 10^{6} \mathrm{PC}-3$ human prostatic cancer cells. Half of the mice ( $\mathrm{N}=10 /$ group) received degarelix at a dose of $10 \mathrm{mg} / \mathrm{kg}$ body weight subcutaneously in a slow-release formula. In another experiment ( $\mathrm{N}=10 / \mathrm{group})$, degarelix treatment was supplemented with recombinant human $\mathrm{FSH}$ at $10 \mathrm{lU} / \mathrm{kg} /$ day using i.p. ALZET osmotic minipumps. Tumour growth was monitored over a 4-week period by external inspection and calliper measurement.

\section{RESULTS:}

1. Degarelix suppressed growth of PC-3 cells in IM and GM male nude mice

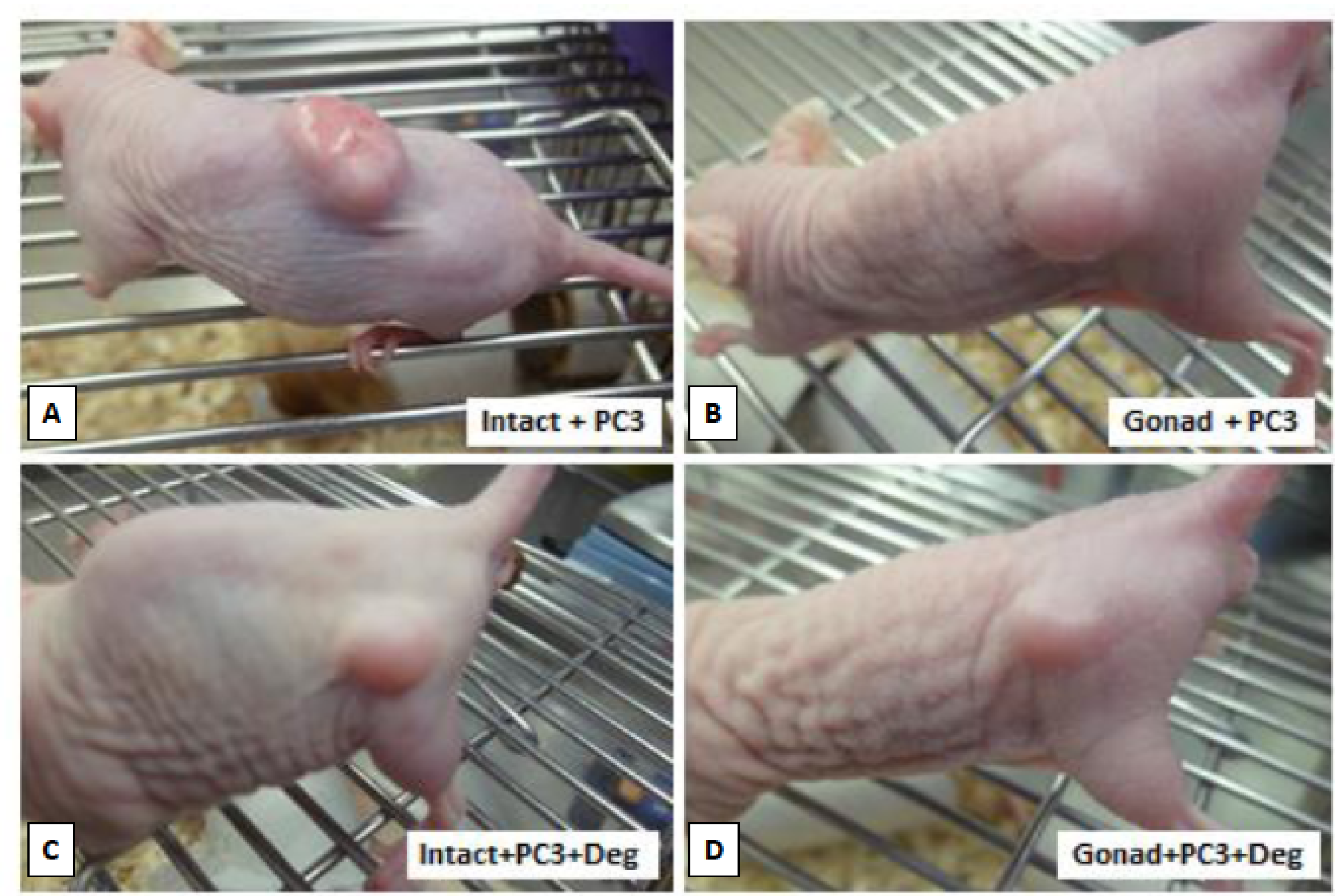

IM and GM nude mice harbouring PC-3 cells xenografts. (A) and (B) controls without treatment. (C) and (D) treatment with degarelix for 4 weeks.

4. Degarelix decreased reproductive organ weights of Intact Mice

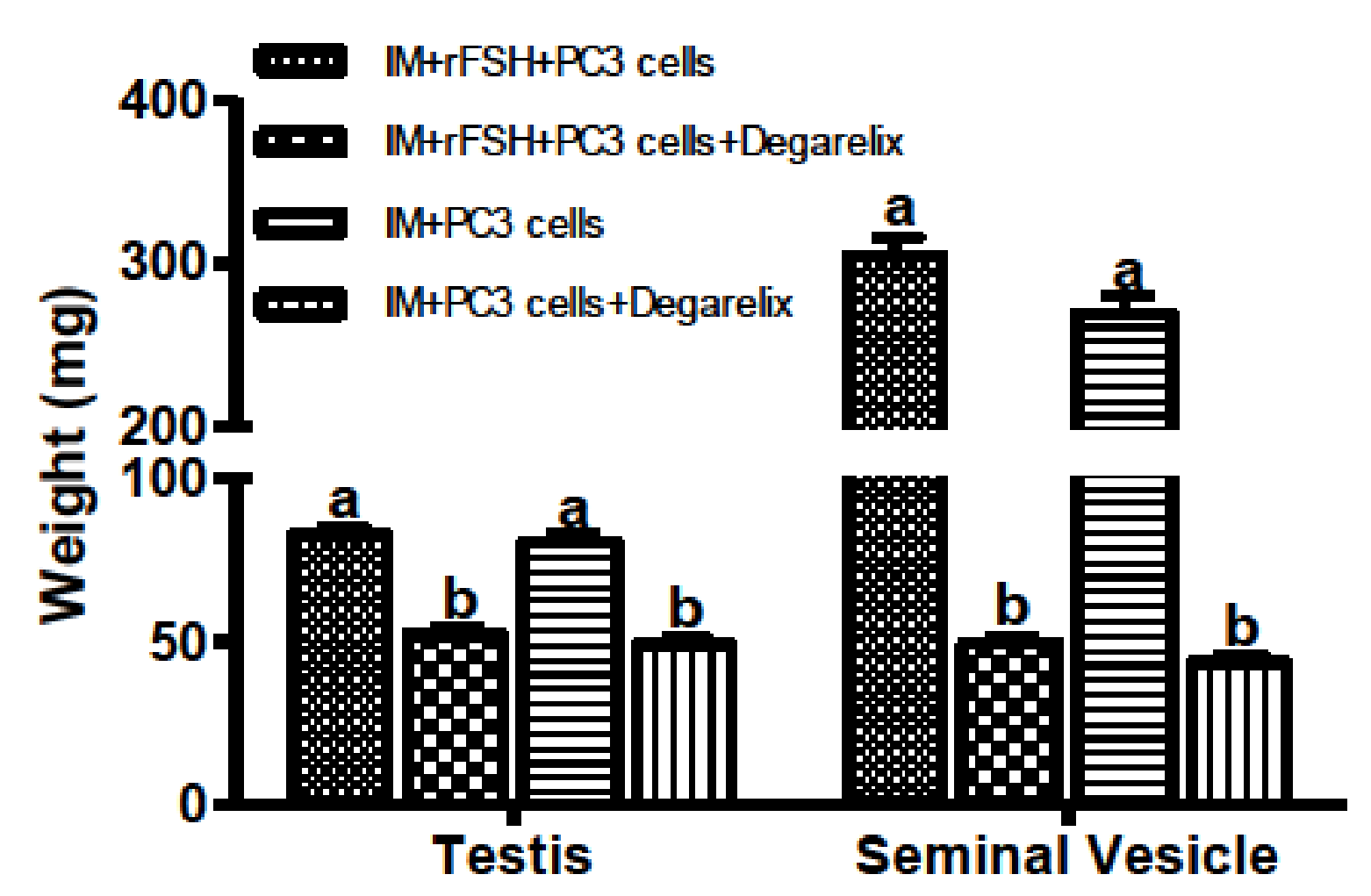

Testes and seminal vesicles weights of controls and degarelix treated mice. Different superscript letters indicates significant differences.

\section{CONCLUSIONS}

1. GnRH antagonist (degarelix) treatment clearly suppresses PC-3 xenograft growth.

2. FSH treatment increases tumour weights in both control and degarelix treated mice.

3. Cultured PC-3 cells do not express FSHR and LHR, but both receptors are expressed in tumours.

4. Similar findings in both groups of mice indicates that testicular function is not involved in growth of the androgen receptornegative PC-3 cells.

5. The findings suggest that the suppression of both gonadotropins by $\mathrm{GnRH}$ antagonist treatment may offer an advantage over GnRH agonist (only LH is permanently suppressed) in the treatment of prostatic cancer.
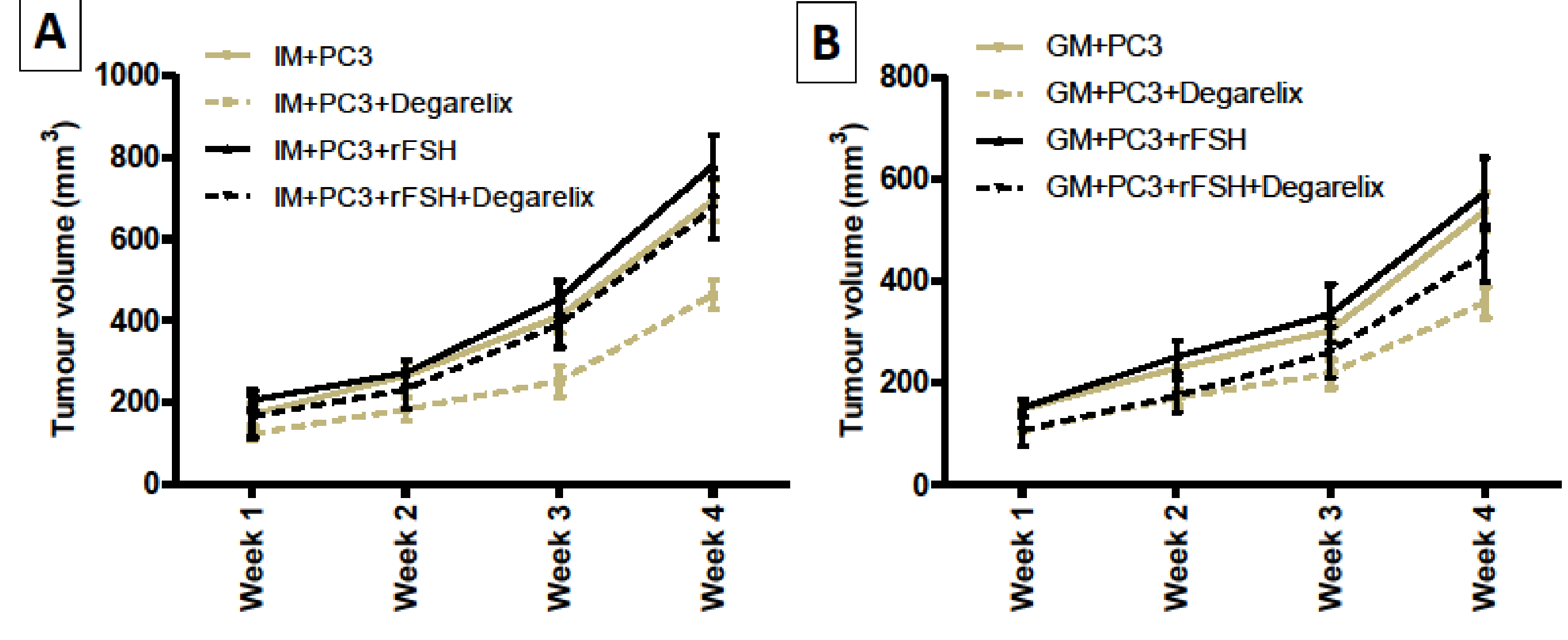

Assessment of tumour volumes over 4 weeks' treatment period in (A) Intact and (B) Gonaded mice ( $\mathrm{N}=10 /$ group). Degarelix treatment reduced tumo compared to non-traned controls ( $\mathrm{p}<0.0001)$, The observed in IM and GM as xenograft growth by degarelix was inhibited by concomitant FSH treatment. Dat are expressed as Mean \pm SEM in all figures.
3. FSH treatment increased tumour size in IM with and without degarelix treatment
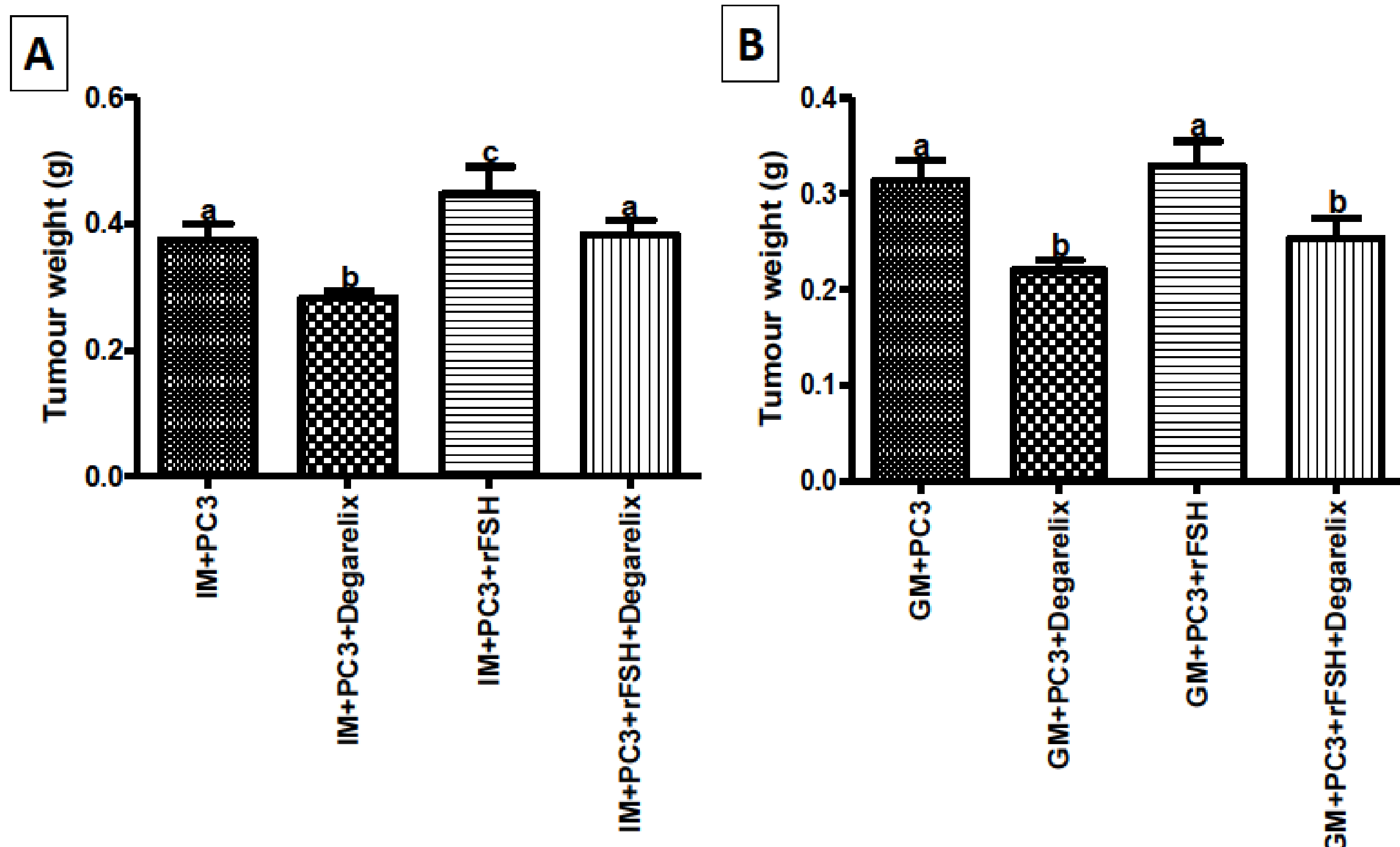

Effect of degarelix and/or human rFSH treatment on final tumour weights. (A) $I M$ and (B) GM. Groups with different superscript letters are significantly different $(p<0.05)$.

5. Tumour xenografts but not original PC-3 cells expressed gonadotropin receptors

A
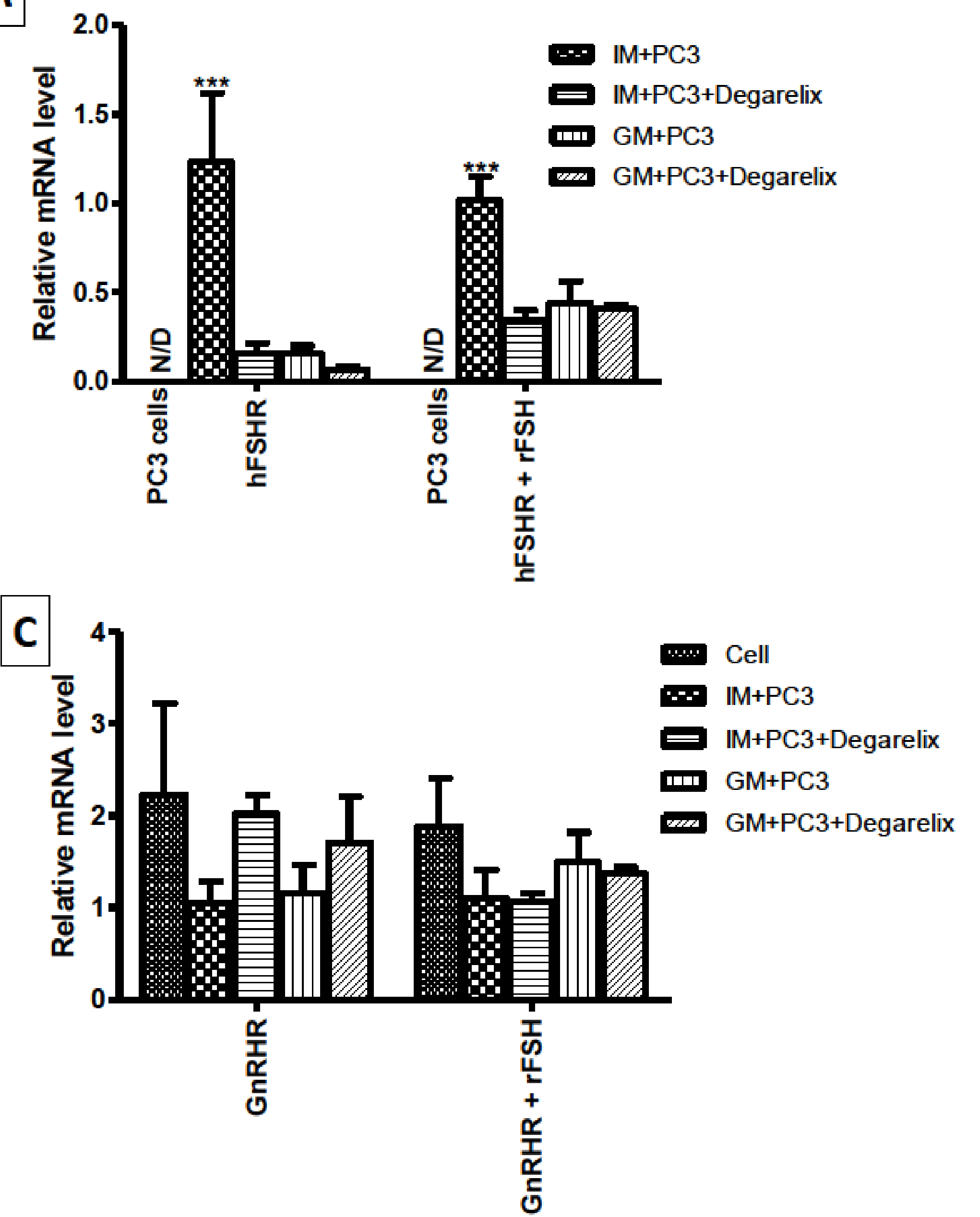

QRT-PCR of tumour mRNA was performed to obtain relative mRNA levefs (A) FSH receptor (R), (B) LHR, (C) GNRH and (D) GNRH-R ( $N=3 /$ group). Non-inoculated PC-3 cells used as controls. The cells did not express either FSHR or LHR.

\section{References:}

1. Shore N. D. et al. Prostate Cancer Prostatic Dis. 2013;16:7-15

2. Huhtaniemi I et al. J Androl 1987;8:355-62

3. Klotz L et al. BJU Int 2008;102:1531-8

\section{Acknowledgements:}

This work was supported by an unlimited grant from Ferring Pharmaceuticals
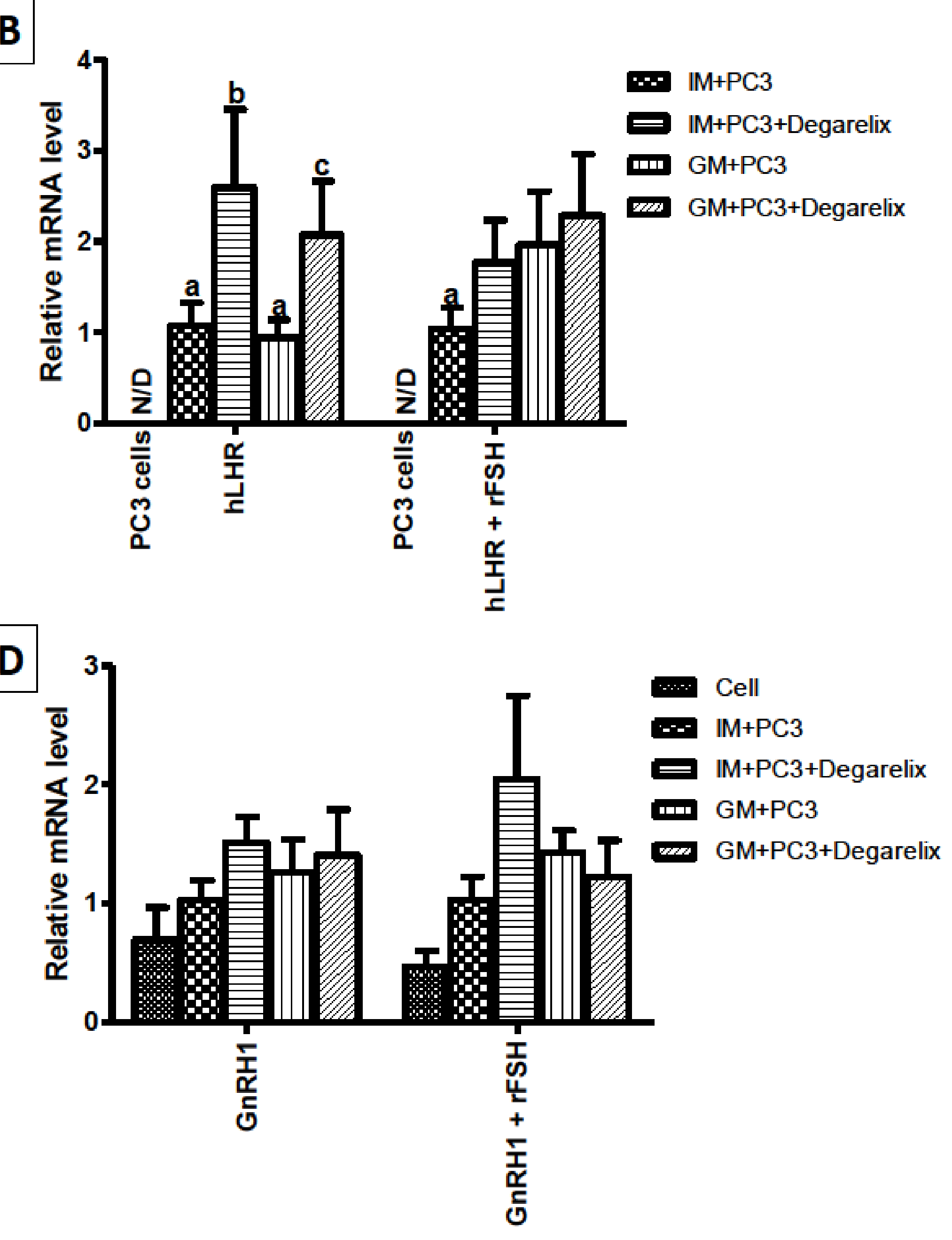